\title{
Community Colleges and the Politics of Sociospatial Scale
}

\author{
By: David F. Ayers
}

Ayers, D. F. (2011). Community colleges and the politics of sociospatial scale. Higher Education: The International Journal of Higher Education Research, 62, 303-314. doi: 10.1007/s10734-010-9388-5.

***Note: This version of the document is not the copy of record Made available courtesy of Springer Publishers. Link to article: http://dx.doi.org/10.1007/s10734-010-9388-5

\begin{abstract}
:
In an analysis of 421 community college mission statements, I demonstrate how community colleges recontextualize a dominant discourse in which economic activity at the global scale transcends regulation, the nation-state lacks the moral authority to influence markets, and local communities have no choice but to adapt. Findings suggest that the community college has appropriated economic development as a mission priority and tacitly accommodated scalar relations typical of post-Fordism. On the other hand, a rival hypothesis suggests a competing trend in which colleges prepare and empower students to engage in sociopolitical processes at a global scale.

\section{Article:}

One feature of neoliberal capitalism is a hegemonic discourse in which economic activity at the global scale transcends regulation, the nation-state lacks the moral authority to influence markets, and local communities have no choice but to adapt (Robertson 1992; Swyngedouw 1997; Uitermark 2002). This discourse sustains a logic in which local communities must compete with one another within a deregulated, free market to attract capital investment, and "what they get out of it is what they deserve" (Swyngedouw 1997). In this analysis, I explore how these constructions of sociospatial scale are accommodated and contested within the institutional context of the community college.
\end{abstract}

It is important to understand how these discourse processes play out within the community college context, because "scale redefinitions alter and express changes in the geometry of social power by strengthening the power and the control of some while disempowering others" (Swyngedouw 1997). My objective is to explore how these redefinitions function ideologically in terms of power relations. This is a compelling intent for the following reasons: (a) rescaling is "a process driven by class, ethnic, gender, and cultural struggles" (Jonas 1994); (b) the community college serves high numbers of students from lower socioeconomic backgrounds as well as cultural and ethnic minorities (Cohen and Brawer 2003); so, (c) it follows that the community college is a likely site of struggle associated with sociospatial rescaling. Unfortunately, the literature suggests that nation-state rescaling not only shifts relations of power against those of very limited means but also obscures the attendant class antagonisms (Uitermark 2002). 
The specific context of this analysis is the community college in the United States; however, because neoliberal capitalism is a global phenomenon, the results may also speak to similar institutions worldwide, such as polytechnics in Finland, universities for applied sciences in the Netherlands, community colleges in Canada, and former polytechnics in the U.K. The U.S. community college, furthermore, has been held up as a model for developing nations to emulate: for example, the Saigon Institute of Technology in Vietnam (Spangler 2009) and the Surabaya Polytechnic Institute in East Java, Indonesia (Prameshwari and Rachman 2010).

\section{THEORETICAL FRAMEWORK AND REVIEW OF RELATED LITERATURE}

Related analyses have explored the spatiotemporal relations among policy texts in the implementation of the Bologna Declaration (Wodak and Fairclough 2010); university-level education and the knowledge-based economy in Europe (Jessop et al. 2008); the marketization of universities in the United Kingdom (Fairclough 1993); and the community college as a component of the state's neoliberal institutional framework (Ayers 2005; Ayers and Carlone 2007). All of these studies were informed by critical discourse analysis and cultural political economy as interdisciplinary approaches to social research. Employing sociological and ethnographic methods, researchers have pursued explored the impact of neoliberal capitalism on higher education globally (Slaughter and Leslie 1997), have theorized this process in the U.S. as academic capitalism (Slaughter and Rhoades 2004), and have discussed the political economy of higher education in the Americas from a critical perspective (Rhoads and Torres 2006). In a separate line of research, scholars have investigated the effects of neoliberal globalization on community colleges (Levin 2001), their faculty (Levin 2006; Levin et al. 2006), and their students (Levin 2007). No analysis to date has explicitly considered processes of sociospatial rescaling for the community college.

\section{The community college}

The community college is unique among institutions of postsecondary education in that it serves predominantly local constituents, although distance learning programs are extending the service area of many community colleges. Distance learning notwithstanding, in most states the community college's scale of operation includes one to three counties or parishes, a metropolitan area, or a well-defined region of the state. More than 1,173 community colleges campuses serve nearly half of all undergraduate learners in the United States (Cohen and Brawer 2003). Because of its geographic dispersion, $90 \%$ of Americans live within 25 miles of a community college (Cohen and Brawer 2003).

Whereas the community college's accessibility is a point of consensus among many scholars, its political-economic impact is highly debated. Dougherty (1994) reviewed competing commentaries on the community college, including functionalist (Clark 1960; Cohen and Brawer 2003), instrumentalist Marxist (Bowles and Gintis 1976; Pincus 1980; Zwerling 1976), and institutionalist (Brint and Karabel 1989) schools. He recognizes some common ground among the three schools of thought: All agree that the community college (a) accommodates capital's demands for labor trained at the taxpayer's expense, and (b) protects the selectivity of elite colleges and universities. Taking up a hotly debated issue, he concludes that the community college reduces the probability of baccalaureate completion, but this is true only if one compares similar students. A particular niche of students - those who have no aspirations for a bachelor's degree-are more likely to pursue at least some postsecondary than they would be in the absence 
of a community college. Indeed, for many students the choice to attend the community college "is not between the community college and a senior residential institution; it is between the community college and nothing” (Cohen and Brawer 2008).

Dougherty (1994) also finds that all three camps overestimate the community college's responsiveness to labor markets. Developing a state-relative autonomy perspective, Dougherty suggests that alongside capital, government officials and local educational leaders have shaped the community college mission as a means of advancing their own interests. In light of Dougherty's conclusions, the community college is not simply a client of capital but instead stands in close relation to what I describe as local growth coalitions, following Holland (2007). These local growth coalitions pressure community colleges into accommodating the interests of global capital. Holland (2007) describes such a local network:

These growth machines are led by place entrepreneurs who seek to maximize property values and rents from buildings and land in a locale, and they include real estate owners, bankers and financiers, building developers, construction firms, and real estate brokers and attorneys. Within growth coalitions, place entrepreneurs are supported by local elected and appointed officials (e.g., mayors, county commissioners), the local media, and some (but not all) small-business proprietors and professionals. (p. 189)

Holland adds that these local growth coalitions lobby for conditions believed to attract capital investment, particularly low taxes, physical infrastructure, so-called "right-to-work" laws, and minimal environmental regulation.

\section{The politics of sociospatial scale}

Sociospatial scale consists in sociospatial entities beginning with the body and expanding outward to include the neighborhood, city, state, nation-state, region, and globe. Swyngedouw (1997) equates scalar relations with "the arena and moment, both discursively and materially, where sociospatial power relations are contested and compromises are negotiated and regulated. Scale, therefore, is both the result and outcome of social struggle for power and control” (Swyngedouw 1997). Today, such struggles involve shifts in vertical relations among the global, national, and local as well as shifts in horizontal relations as communities across the nation compete with one another to attract capital investment. As a consequence of these discursive constructions of sociospatial scale, the nation state is associated with dysfunction, lethargy, and intransigence, whereas everything global is associated with efficiency, responsiveness, and progress (Rhoads and Torres 2006). This discourse animates competitive strategies in which the nation-state lacks the moral authority to influence markets, economic activity at the global scale transcends regulation, and local communities have no choice but to adapt (Swyngedouw 1997). It naturalizes and legitimizes capital disinvestment if localities fail to adopt "business-friendly" competitive policies, which usually entail incentives such as tax breaks and state-sponsored job training. Within this milieu, working class communities-led by local growth coalitionscompete with one another to attract external investment and eagerly subordinate community, family, and individual needs to the demands and interests of capital (Ayers and Carlone 2007; Ayers et al. 2008). 
Swyngedouw (1997) associates rescaling, specifically the collapse of Atlantic Fordism and the subsequent rise of the post-Fordist regime of accumulation, with four macro-social outcomes. First, in the Fordist system tensions between capital and labor were managed at the national scale; however, in the post-Fordist regime of accumulation, capital has "jumped” scale such that it evades the authority of the nation-state. At the same time, the management of labor has devolved to the local scale, resulting in a significant weakening of labor organization. Second, national concerns for welfare and a safety net have eroded, and thus economic risks have been de-scaled down to the local-even to the individual body (see also Sandlin 2004). Third, processes of economic intervention are rescaled upward in the case of the World Trade Organization and G8 and downward in the case of local competitive regimes. Fourth, this rescaling of authority leads to autocratic, undemocratic, and authoritarian modes of governance, particularly given the agency of global organizations such as the World Bank, International Monetary Fund, and Organization for Economic Co-operation and Development (OECD), which are not subject to democratic accountabilities. Swyngedouw adds that local growth regimes are notorious for their absence of democratic practices.

This set of scalar relations is not arbitrary. Indeed, there is competition among factions to mobilize discourses which advance their interests. Godin (2004, 2006), for example, demonstrates how the OECD has played a prominent role in advancing a specific economic narrative - that of the knowledge-based economy. Godin (2004) discusses specific genres which OECD personnel are expected to produce. One such genre is the academic publication, which is exemplified by a scholarly journal titled Higher Education Management and Policy (for example, Goddard and Puukka 2008). According to Godin (2004), these publications “organise the discourse into a policy-oriented framework, using buzzwords”. According to Jessop et al. (2008) these reports are prepared for consumption by ministers and policymakers at various scales from national to local. Predictably, the reports establish a certain model of economic development as a goal, threats to economic growth as a problem, and preparation of a globally competitive workforce as part of the solution. Discussing higher education in the Americas from a critical political economy perspective, Torres and Rhoads (2006) find four similar themes: (a) efficiency and accountability, (b) accreditation and universalization, (c) international competitiveness, and (d) privatization.

At a national scale, at least in the U.S., discourses are promulgated in the form of presidential speeches, press releases, and reports issued by federal entities such as the Department of Education and the Department of Labor. The latter administers the Workforce Investment Act (WIA), which provides for a comprehensive system of workforce development. The aim of the legislation is to match up labor supply and employer demand. Even though the WIA is federal legislation, decision making is scaled down to the state-local level, for example, to local workforce development boards. Quite possibly, these boards are made up of the same individuals who constitute local growth coalitions.

\section{Recontextualization}

Even local interpretations of economic processes draw on, borrow from, or reproduce discourses originating at more global scales (Wodak and Fairclough 2010). As such, an analysis of discourse processes at a local scale must take into account those at more global scales, the ways such discourses are translated into local practices, and how these manifest empirically as texts. 
Wodak and Fairclough (2010), for example, traced the implementation of the Bologna Process from the supra-national/regional scale to the national scale, using Romania and Austria as case studies. Their analysis centered upon the CDA category of recontextualization, which provided "a fine-grained account" of the implementation, enforcement, and application of policy at the national scale. Wodak and Fairclough (2010: 22) were interested in "glocalization” as a discursive process, or "how more global processes are being implemented, recontextualized, and thus changed on local/regional/national levels”. Wodak and Fairclough (2010: 22) suggest that

spatial and temporal relationships between texts include relations of recontextualization whereby texts (and the discourses and genres which they deploy) move between spatially and temporally different contexts, and are subject to transformations whose nature depends upon relationships and differences between such contexts.

As indicated above, Wodak and Fairclough examined texts with an interest in three dialectically related linguistic elements: (a) genres, or the particular ways a text is organized and deployed; (b) discourses, or the ways language represents some aspect of the work; and (c) styles, or the ways identities are constructed through language.

\section{METHODS}

To explore the recontextualization of global scalar discourses within the community college as a societal institution, I selected critical discourse analysis (CDA). CDA is an interdisciplinary approach to social research based in a dialectical-relational version of critical realist ontology (Bhaskar 1986, 1998; Fairclough et al. 2004). Methodologically, critical discourse analysis provides one "point of entry" into a social process such as recontextualization (Jessop et al. 2008; Wodak and Fairclough 2010). In this view, discourse is one of many dialectically related moments, or mechanisms, which determine social processes (Fairclough et al. 2004; Harvey 1996). Social processes such as scalar relations are, however, fundamentally discursive and, as such, can be explored at the first level of approximation through discourse analysis.

\section{Data}

Discourse manifests empirically as text, and so discourse analysis is operationalized as textual analysis. In this analysis, I chose community college mission statements as textual data. This decision can be justified from three related angles. First, regional accrediting bodies require institutions to produce mission statements (Keller 1983), so the documents emerge at least in part in an attempt to establish institutional legitimacy (DiMaggio and Powell 1991; Powell and DiMaggio 1991). Second, the production of mission statements establishes a unique role for educational institutions and thus promotes institutional autonomy within a environment dominated by a corporate institutional forms (Connell and Galasinski 1998). Third, mission statements do not simply describe but also interpret reality, which constitutes an act of governance (Tierney 2008). A mission statement, then, can be considered an outcome of organizational politics. It is, in other words, a symbolic artifact of institutional culture (Morphew 2006). In sum, discursive practice as manifest in mission statements functions toward sociopolitical ends (Bakhtin et al. 1986; Fairclough 1989, 1992; Foucault 1980).

The data for this study included 421 mission statements retrieved from the 2008 Integrated Postsecondary Education Data System (IPEDS). I queried the IPEDS database using the 
following criteria: (a) public institution, (b) within the 50 states but not outlying areas such as the Virgin Islands, (d) associates degree as highest degree offered. The query returned over a thousand institutions; however, only 421 of these provided full text of mission statements. In the end, the corpus of mission statements represented 421 community colleges located within 43 states.

The literature on sociospatial scale provided the theoretical lens, which guided the analysis. I focused on discourses related to sociospatial scale, but since discourses are dialectically related to-and thus analytically inseparable from-genres and styles, I was mindful of these as well. The analysis was recursive, and I produced notes, formulated running hypotheses, and searched for rival hypotheses and contradictory evidence throughout each round of analysis.

\section{FINDINGS}

Community colleges are community-based institutions with local service areas, so it is no surprise that their missions are contextualized primarily at a local scale. At the least, the title "community" college intimates a scalar discourse of the local. Surprisingly, however, only three institutions in the data set cite the scale of the nation-state as a context for the institutional mission. In contrast, 82 texts situate the institutional mission within a global context. In an analysis of these 82 mission statements and the representations of scale therein, I found that the context is described as a global economy, global socio-economic system, global society, or similar representations of global scale. These terms appear with very few exceptions as objects of prepositions, not subjects of sentences or even objects of verbs. There are no claims that such a global context exists, nor is there any justification for such assumptions. The global context is rendered to background knowledge, or knowledge assumed to be shared with the consumer of the text, or the reader. Scalar discourses, in other words, are appropriated from external sources and tacitly accommodated.

\section{A globally competitive workforce}

Table 1 provides five exemplary text segments in which a discourse of global scale is invoked. Twenty-nine of the texts invoking a discourse of global scale shared in common a theme of economic development in which localities adapt to global economic processes. Consistent with discourses at other sites and scales, particularly the OECD, these texts emphasize competition; adaptation; and the improvement of knowledge, skills, and attitudes valued by employers. Further, lifelong learning, or perpetual skill upgrading is portrayed as a requirement for an individual's economic wellbeing. Example 1 demonstrates the market logics emanating from the global scale and reproduced at the national scale. Specifically, the community college exists to mediate between the unemployed and business and industry. The intent is to match up supply and demand - a fundamentally economic discourse typical of the national policy context. In this example, learners are objectified as “employees", which are provided for business and industry in the form of a commodity. Here, the client of the community college is business and industry, and students are constructed as passive objects. 
Table 1 Text segments invoking a global scale and a theme of workforce competitiveness

\begin{tabular}{|c|c|c|c|c|}
\hline & State & Inst. size & Deg. & Text \\
\hline 1 & LA & $<1,000$ & Town & $\begin{array}{l}\text { [College] ... delivers instructional programs which provide } \\
\text { skilled employees for business and industry that contribute to } \\
\text { the overall economic development and workforce needs of the } \\
\text { state }\end{array}$ \\
\hline 2 & WI & $1,000-4,999$ & City & $\begin{array}{l}\text { [College] ....is the customer-focused- accessible provider of } \\
\text { innovative life-long learning that builds a globally competitive } \\
\text { workforce }\end{array}$ \\
\hline 3 & $\mathrm{NC}$ & $1,000-4,999$ & Town & $\begin{array}{l}\text { [College provides] “....services to and partnerships with } \\
\text { business and industry to promote economic development in a } \\
\text { global environment” }\end{array}$ \\
\hline 4 & CA & $\begin{array}{l}10,000- \\
19,999\end{array}$ & City & $\begin{array}{l}\text { "The College advances state- region- and local economic } \\
\text { growth and global competitiveness through education- training } \\
\text { and services that contribute to workforce improvement" }\end{array}$ \\
\hline 5 & $\mathrm{OH}$ & $\geq 20,000$ & & $\begin{array}{l}\text { "The college will proactively respond to the changing needs of } \\
\text { our community and its role in the global economy through the } \\
\text { use of instructional and emerging technologies" }\end{array}$ \\
\hline
\end{tabular}

LA Louisiana, WI Wisconsin, NC North Carolina, CA California, OH Ohio, Inst. Size institution size, Deg. degree of urbanization

Examples 3 and 4 reproduce a similar discourse: Services are provided to business and industry, but in these examples the learners are omitted entirely. These text segments demonstrate nominalization, a linguistic strategy in which complex social processes are reduced to a noun (Fairclough 1995). As such, the process can be referenced without inviting ideological contestation. Similar discourses are apparent in Examples 2 and 3. Example 2 is marked by catch-phrases and buzzwords typical of OECD reports: "customer”, "innovative”, "a globally competitive workforce", and "life-long learning". Example 3 is marked by reference to partnerships with business and industry. At the global and national scales, the purpose of these partnerships, in the words of President Barack Obama, is "to create programs that match curricula in the classroom with the needs of the boardroom" (Office of the Press Secretary 2009).

\section{Citizenship and responsibility in a global community}

Competitive and economic development discourses do not account for the global context represented by all mission statements in this study, however. Within the subset of 82 mission statements invoking a global discourse, 32 espouse a broader vision for students, which includes a language of empowerment. The purpose of the college, in these text segments, is to prepare students to participate in, succeed in, or develop awareness of a global community. Table 2 provides examples. The representations of the college, the relations between students and faculty, and the role of graduates in society contrast those in Table 1 . The tone is less utilitarian and much more humanistic. The language is much more typical of a democratic philosophy of education. Key terms include "collaboration”, “empower”, "responsibility”, "intellectual rigor”, "aesthetic appreciation”, "respect”, “citizenship”, and "leaders”. 
Table 2 Text segments invoking a global scale and a theme of empowerment

\begin{tabular}{|c|c|c|c|c|}
\hline & State & Inst. Size & Deg. & Text \\
\hline 1. & GA & $1,000-4,999$ & Town & $\begin{array}{l}\text { Through close collaboration with faculty and staff- } \\
\text { students are engaged in educational opportunities that } \\
\text { empower them for success in a sustainable global society }\end{array}$ \\
\hline 2. & CT & 5,000-9,999 & City & $\begin{array}{l}\text { We prepare students to participate in- and contribute } \\
\text { responsibly to- our global society }\end{array}$ \\
\hline 3. & LA & $1,000-4,999$ & City & $\begin{array}{l}\text { The mission, in part, is “...to promote lifelong learning- } \\
\text { intellectual rigor- aesthetic appreciation- respect for } \\
\text { individual and world views- and responsible citizenship } \\
\text { both locally and globally” }\end{array}$ \\
\hline 4. & CA & $10,000-19,999$ & City & $\begin{array}{l}\text { Our purpose is to foster a learning environment that helps } \\
\text { students develop... a commitment to local and global } \\
\text { citizenship }\end{array}$ \\
\hline 5. & CA & 10,000-19,999 & Rural & $\begin{array}{l}\text { The college "...seeks to develop community leaders who } \\
\text { can participate responsibly in a democratic society and } \\
\text { become global stewards in a dynamic world economy" }\end{array}$ \\
\hline
\end{tabular}
GA Georgia, CT Connecticut, LA Louisiana, CA California, Inst. Size institution size, Deg. degree of urbanization

It is instructive to note the agency afforded to students in Examples 1-5. Specifically, learners are constructed as active human agents—not passive objects. Learners are omitted in Example 3; however, once again the style constructed for students is that of an engaged citizen-not a passive participant in the labor market. Example 5 sets the context of a global economy, but students are constructed as "stewards", which implies not only agency but also responsibility. The difference is important, because stewards have an ethical responsibility. As construed by economic discourses, participants in the labor market, on the other hand, are responsible for lifelong learning and economic productivity, which attracts capital investment and is required for material wellbeing.

\section{Degree of urbanization and institutional size}

In the analysis of those mission statements invoking a scalar discourse of the global, two patterns emerged. First, community colleges associated with a higher degree of urbanization were more likely to situate their mission within a global context (see Table 3). This trend was statistically significant, $\mathrm{X} 2(3, \mathrm{~N}=421)=8.37, \mathrm{p}=0.039$. Second, and related to the first trend, the mission of larger institutions was more frequently situated within a global context (see Table 4). This trend was also statistically significant, $X^{2}(4, N=421)=18, p=0.0012$. It should be noted that representation of institutions with more than 20,000 students was inadequate for full reliability. Further, Chi-square analysis involves the assumption of random sampling, which was not the case in this study. As such, these trends should be interpreted with caution until they can be verified in future studies. 
Table 3 Texts invoking global scalar discourse by degree of urbanization $(N=421)$

\begin{tabular}{llllll}
\hline Degree of urbanization & Total $n$ & Observed & Expected & П Observed & П Expected \\
\hline City & 119 & 33 & 23.21 & 0.28 & 0.28 \\
Suburb & 67 & 16 & 13.04 & 0.24 & 0.16 \\
Town & 102 & 14 & 19.84 & 0.14 & 0.24 \\
Rural & 133 & 19 & 25.91 & 0.14 & 0.32 \\
Totals & 421 & 82 & 82 & 0.195 & 0.195 \\
\hline
\end{tabular}

$X^{2}(3, N=421)=8.37, p=0.039$

Table 4 Texts invoking global scalar discourse by institution size $(N=421)$

\begin{tabular}{llllll}
\hline Institution size & Total $n$ & Observed & Expected & П Observed & П Expected \\
\hline$<1,000$ & 47 & 3 & 9.1 & 0.06 & 0.11 \\
$1,000-4,999$ & 207 & 29 & 40.3 & 0.14 & 0.49 \\
$5,000-9,999$ & 87 & 23 & 17 & 0.26 & 0.21 \\
$10,000-19,999$ & 57 & 20 & 11 & 0.35 & 0.14 \\
$>20,000$ & 23 & 7 & 4.6 & 0.30 & 0.06 \\
Totals & 421 & 82 & 82 & 0.195 & 0.195
\end{tabular}

$X^{2}(4, N=421)=18, p=0.0012$

\section{Economic development mission}

Another salient finding of this analysis was that community colleges in this data set have appropriated an economic mission in large numbers, with 133 (31.6\%) identifying economic development as a mission priority. Analysis of the 133 text segments representing this economic development mission indicated that development was targeted primarily at an unspecified scale, $n=46$ (34.6\%). This ambiguous targeting of scale is exemplified by the following bulleted statement: "Serve our community as a learning-centered institution to build a globally competitive workforce supporting economic development.” In this example, economic development, which is a complex and ideologically laden process, is represented through nominalization. As a noun, economic development is easily regarded as a natural fact of social life-a commonsense, apolitical project which is not to be disputed.

On the other hand, sociospatial scale was specified in other text segments describing economic development as a mission priority. First, 25 (19\%) identified a community scale with language similar to the following two examples: (a) the college "contributes to the economic growth of the community", and (b) The purpose of the college is "to address the local and global educational needs of our community". Similarly, 19 (14\%) identified a region of the state as the scale of economic development activity. Two examples follow: (a) The college "enhances the quality of life and economic vitality of our region", and (b) "We endeavor to promote economic development through community engagement and workforce development for the region." Similar language identified the scale as the college's service area $(n=16 ; 12 \%)$, the state $(n=8$; $6 \%)$, the individual body ( $3 ; 2 \%)$, and other vague scales such as businesses, society, and "groups" $(15 ; 11 \%)$. In sum, economic development is situated within a global context, but the 
entities responsible for developing a competitive advantage are decidedly local—most commonly communities and regions of the state.

\section{DISCUSSION}

It is instructive to interpret these findings against the backdrop of a post-Fordist mode of production as described above. Economic risks and competitive responsibility are descaled down to the local. Within today's post-Fordist mode of production, this scheme is seen as producing beneficial outcomes for all involved, as corporations increase productivity at lower costs, local residents gain employment, and members of local growth coalitions advance their interests. A fundamental assumption in this scheme is that investment in education will result in increased earnings for students (Schultz 1977). While this is typically the case, the competitive environment enables capital to play labor in one locality against labor in another locality (Uitermark 2002). As such, the winning bidder-that is, the locality that recruits capital to its location-successfully negotiates minimal compensation and rights for its workers. For this reason, students do not benefit equitably in comparison to capital, which not only increases the rate of exploitation (Marx and McLellan 1995) but also displaces criticism for low wages, environmental degradation, and alienation of workers' rights through a discourse of global competitiveness (Uitermark 2002).

Quite often, such logics and assumptions are tacitly accommodated. Indeed, the "rights of corporate elites to invest corporate resources wherever they wish, at lowest cost to them, or to disinvest from communities in accordance with self-interested market logics, all in the name of growth, go entirely unquestioned” (Holland 2007). As these costs remain veiled, so do class antagonisms. Instead of implicating class relations, this hegemonic set of assumptions fragments working class solidarity (Uitermark 2002). Workers who lose their jobs when a corporation leaves the locality bear the costs in that they once again must seek employment and often retraining. Essentially, the community college as represented in this discourse provides an endless “boot camp” for what Marx sees as a reserve army of laborers (Marx and McLellan 1995).

This discourse is not fully representative of the community college, however. The search for rival hypotheses revealed an empowering discourse, which could be interpreted as an attempt to help students and communities “jump scales" and become engaged in global as well as local processes. Such an effort could be interpreted as an act of power, because as suggested above, scalar relations are power relations. Place-bound students are at a disadvantage under current constructions of sociospatial scale, whereas those capable of navigating the global milieu have a greater capacity to act in their own interests. Such efforts to increase students' global mobility stand in contrast to post-Fordist norms in which capital is globally mobile and labor is place bound and thus dependent upon external investment.

\section{CONCLUSION}

Given the premise that scales are relational, it is a mistake to accept the dominant narrative in which the global is uncritically associated with mobility and the national with entrenchment. Indeed, contrary to neoliberal claims, many political-economic geographers agree that there is no objective, empirically optimal scalar location of any given political economic function (Peck 2002; Swyngedouw 1997; Uitermark 2002). As such, today's common sense-which holds that 
global markets are naturally free, nation-states should not intervene in markets, and local communities have no choice but to adapt—is at best a set of half truths. Unfortunately, the socially constructed nature of sociospatial scale is rarely recognized in today's cultural milieu. In this analysis, I described how community colleges recontextualize contemporary discourses of sociospatial scale, and I interpreted the ideological consequences. Findings suggest that the community college is a site of ideological struggle in which scalar relations - and the positioning of students and communities therein-are both accommodated and contested.

\section{REFERENCE}

Ayers, D. F. (2005). Neoliberal ideology in community college mission statements: A critical discourse analysis. The Review of Higher Education, 28, 527-549.

Ayers, D. F., \& Carlone, D. (2007). Manifestations of neoliberal discourses in a local jobtraining program. International Journal of Lifelong Education, 26, 461-479.

Ayers, D. F., Miller-Dyce, C., \& Carlone, D. (2008). Security, dignity, caring relationships, and meaningful work: Needs motivating participation in a job-training program. Community College Review, 35, 257-276.

Bakhtin, M. M., Holquist, M., \& Emerson, C. (1986). Speech genres and other late essays. Austin: University of Texas Press.

Bhaskar, R. (1986). Scientific realism and human emancipation. London: Verso Editions.

Bhaskar, R. (1998). Critical realism and dialectic. In M. Archer, R. Bhaskar, A. Collier, T. Lawson, \& A. Norrie (Eds.), Critical realism: Essential readings (pp. 575-640). London: Routledge.

Bowles, S., \& Gintis, H. (1976). Schooling in capitalist America. New York: Basic Books.

Brint, S. G., \& Karabel, J. (1989). The diverted dream: Community colleges and the promise of educational opportunity in America, 1900-1985. New York: Oxford University Press.

Clark, B. R. (1960). The 'cooling out' function in higher education. American Journal of Sociology, 65, 569-576.

Cohen, A. M., \& Brawer, F. B. (2003). The American community college. San Francisco: JosseyBass.

Cohen, A. M., \& Brawer, F. B. (2008). The American community college. San Francisco: JosseyBass.

Connell, I., \& Galasinski, D. (1998). Academic mission statements: An exercise in negotiation. Discourse and Society, 9, 457-479. 
DiMaggio, P., \& Powell, W. (1991). The iron cage revisited: Institutional isomprphism and collective rationality in organizational fields. American Sociological Review, 48, 147160.

Dougherty, K. J. (1994). The contradictory college: The conflicting origins, impacts, and futures of the community college. Albany: State University of New York Press.

Fairclough, N. (1989). Language and power. London, New York: Longman.

Fairclough, N. (1992). Discourse and social change. Cambridge, UK; Cambridge, MA: Polity Press.

Fairclough, N. (1993). Critical discourse analysis and the marketization of public discourse: The universities. Discourse and Society, 4, 133-168.

Fairclough, N. (1995). Critical discourse analysis: The critical study of language. London, New York: Longman.

Fairclough, N., Jessop, B., \& Sayer, A. (2004). Critical realism and semiosis. In J. Joseph \& J. M. Roberts (Eds.), Realism, discourse and deconstruction (pp. 23-42). London: Routledge.

Foucault, M. (1980). Power/knowledge: Selected interviews and other writings in 1972-1977 (C. Gordon, Trans.). New York: Pantheon Books.

Goddard, J., \& Puukka, J. (2008). The engagement of higher education institutions in regional development: An overview of the opportunities and challenges. Higher Education Management and Policy, 20(2), 3-33.

Godin, B. (2004). The new economy: What the concept owes to the OECD. Research Policy, 33, $679-690$.

Godin, B. (2006). The knowledge-based economy: Conceptual framework of buzzword? Journal of Technology Transfer, 31(1), 17-30.

Harvey, D. (1996). Justice, nature, and the geography of difference. Cambridge, MA: Blackwell Publishers.

Holland, D. C. (2007). Local democracy under siege: Activism, public interests, and private politics. New York: New York University Press.

Jessop, B., Fairclough, N., \& Wodak, R. (2008). Education and the knowledge-based economy in Europe. Rotterdam: Sense Publishers.

Jonas, A. (1994). Editorial. Environment and planning D: Society and space, 12, 257-264. 
Keller, G. (1983). Academic strategy: The management revolution in American higher education. Baltimore: Johns Hopkins University Press.

Levin, J. S. (2001). Globalizing the community college: Strategies for change in the twenty-first century. New York: Palgrave.

Levin, J. S. (2006). Faculty work: Tensions between educational and economic values. Journal of Higher Education, 77, 62-88.

Levin, J. S. (2007). Nontraditional students and community colleges: The conflict of justice and neoliberalism. New York: Palgrave Macmillan.

Levin, J. S., Kater, S., \& Wagoner, R. L. (2006). Community college faculty: At work in the new economy. New York: Palgrave Macmillan.

Marx, K., \& McLellan, D. (1995). Capital: An abridged edition. Oxford, New York: Oxford University Press.

Morphew, C. C. (2006). Mission statements: A thematic analysis of rhetoric across institution type. Journal of Higher Education, 77, 456-472.

Office of the Press Secretary. (2009). Remarks by the President on the American Graduation Initiative. Warren, MI: The White House.

Peck, J. (2002). Political economies of scale: Fast policy, interscalar relations, and neoliberal workfare. Economic Geography, 78, 331-361.

Pincus, F. L. (1980). The false promises of community colleges: Class conflict and vocational education. Harvard Educational Review, 50, 332-361.

Powell, W., \& DiMaggio, P. (1991). The new institutionalism in organizational analysis. Chicago: The University of Chicago Press.

Prameshwari, P., \& Rachman, A. (2010). Community colleges offer skills-based learning. Jakarta, Indonesia: Jakarta Globe.

Rhoads, R. A., \& Torres, C. A. (2006). The university, state, and market: The political economy of globalization in the Americas. Stanford, CA: Stanford University Press.

Robertson, R. (1992). Globalization: Social theory and global culture. London: Sage.

Sandlin, J. A. (2004). "It's all up to you”: How welfare-to-work educational programs construct workforce success. Adult Education Quarterly, 54, 89-104.

Schultz, T. W. (1977). Investment in human capital. In J. Karabel \& A. H. Halsey (Eds.), Power and ideology in education (pp. 313-324). New York: Oxford University Press. 
Slaughter, S., \& Leslie, L. L. (1997). Academic capitalism: Politics, policies, and the entrepreneurial university. Baltimore: Johns Hopkins University Press.

Slaughter, S., \& Rhoades, G. (2004). Academic capitalism and the new economy: Markets, state, and higher education. Baltimore: Johns Hopkins University Press.

Spangler, M. (2009). “Working to offer U.S. debrees in Vietmam” Community College Times. Washington, DC: American Association of Community Colleges.

Swyngedouw, E. (1997). Neither global nor local: “Glocalization” and the politics of scale. In K. R. Cox (Ed.), Spaces of globalization: Reasserting the power of the local (pp. 137-166). New York: The Guilford Press.

Tierney, W. G. (2008). The impact of culture on organizational decision making: Theory and practice in higher education. Sterling, VA: Stylus.

Torres, C. A., \& Rhoads, R. A. (2006). Introduction: Globalization and higher education in the Americas. In R. A. Rhoads \& C. A. Torres (Eds.), The university, state, and market: The political economy of globalization in the Americas (pp. 3-38). Stanford, CA: Stanford University Press.

Uitermark, J. (2002). Re-scaling, 'scale fragmentation' and the regulation of antagonistic relationships. Progress in Human Geography, 26, 743-765.

Wodak, R., \& Fairclough, N. (2010). Recontextualizing European higher education policies: The cases of Austria and Romania. Critical Discourse Studies, 7, 19-40.

Zwerling, S. (1976). Second best: The crisis of the community college. New York: McGrawHill. 